\title{
INFLUENCE OF VEHICLES AND PENETRATION ENHANCERS ON ANTI-INFLAMMATORY EFFECT OF 18- $\beta$ GLYCYRRHETINIC ACID: KINETIC MODELLING OF DRUG RELEASE, IN VIVO AND EX VIVO EXPERIMENTS
}

\author{
ECEM FATMA KARAMAN ${ }^{1}$, BURAK ÇELIK ${ }^{2}$, SAMET ÖZDEMIR ${ }^{3}$, EVRIM KEPEKÇI \\ TEKKELI $^{4}$, ASLI BARLA DEMIRKOZ ${ }^{5,6}$, ÜMIT GÖNÜLLÜ ${ }^{1}$, MELIKE ÜNER $^{1 *}$ \\ ${ }^{1}$ Istanbul University, Faculty of Pharmacy, Department of Pharmaceutical Technology, Beyazit 34116, Istanbul, Turkey \\ ${ }^{2}$ Bezmialem Vakif University, Faculty of Pharmacy, Department of Pharmaceutical Technology, Adnan Menderes Bulvari, \\ Vatan Caddesi, Fatih 34093, Istanbul, Turkey \\ ${ }^{3}$ Yeditepe University, Faculty of Pharmacy, Department of Pharmaceutical Technology, Inonu Mah., Kayisdagi Cad., 26 \\ Agustos Yerlesimi, Atasehir 34755, Istanbul, Turkey \\ ${ }^{4}$ Bezmialem Vakif University, Faculty of Pharmacy, Department of Pharmaceutical Analytical Chemistry, Adnan Menderes \\ Bulvari, Vatan Caddesi, Fatih 34093, Istanbul, Turkey \\ ${ }^{5}$ Department of Research and Development Center, Aromsa Flavours and Food Additives San. ve Tic. A.S., Kocaeli, Turkey \\ ${ }^{6}$ Haliç University, Faculty of Engineering, Sütlüce, Beyoğlu 34445, Istanbul, Turkey
}

*corresponding author: melikeuner@yahoo.com

\begin{abstract}
Topical formulations of 18- $\beta$ glycyrrhetinic acid (18- $\beta$ GA) were designed for use in relieving inflammatory and painful conditions of the skin. Formulations were containing penetration enhancers that differ in penetration enhancing mechanisms. Anti-inflammatory effects of formulations and effects of penetration enhancers on penetration and permeation of the drug through rat skin were investigated. The total amount of 18- $\beta$ GA permeated from the base oil/water emulsion $(53.19 \pm 22.25$ $\left.\mathrm{mcg} / \mathrm{cm}^{2}\right)$ was approximately twice higher than the base oleaginous cream $\left(29.17 \pm 3.85 \mathrm{mcg} / \mathrm{cm}^{2}\right)$ while there was no $18-\beta$ GA permeation from the base hydrogel formulation to the skin $(p<0.05)$. Incorporation of propylene glycol was generally found to increase 18- $\beta$ GA permeation to the skin. The highest oedema inhibiting activity was achieved in the oil/water emulsion containing propylene glycol followed by the base oil/water emulsion without a penetration enhancer $(p<0.05)$. This result was consistent with the ex vivo study. Limonene and oleic acid were found to be insufficient in 18- $\beta$ GA permeation to the skin.
\end{abstract}

\section{Rezumat}

Au fost elaborate formulări topice ale acidului gliciretinic 18- $\beta$ (GA 18- $\beta$ ), cu promotori de penetrare, pentru utilizarea acestora în ameliorarea bolilor inflamatorii ale pielii. Au fost cercetate efectele antiinflamatoare ale formulărilor și efectele promotorilor de penetrare asupra penetrării și permeării medicamentului prin pielea şobolanului. Cantitatea totală de $18-\beta$ GA pătrunsă în piele din emulsia de bază U/A $\left(53,19 \pm 22,25 \mathrm{mcg} / \mathrm{cm}^{2}\right)$ a fost aproximativ de două ori mai mare decât din crema oleaginoasă $\left(29,17 \pm 3,85 \mathrm{mcg} / \mathrm{cm}^{2}\right)$. Nu a existat o permeare de $18-\beta$ GA din formularea hidrogelului de bază $(p<0,05)$. Încorporarea propilenglicolului a crescut permeabilitatea GA-18- $\beta$ în piele. Cea mai mare activitate de inhibare a edemelor a fost obținută cu emulsia U/A conținând propilenglicol, urmată de emulsia U/A de bază fără promotor de penetrare $(p<0,05)$. Acest rezultat a fost în concordanță cu studiul ex vivo. Limonenul și acidul oleic s-au dovedit a fi insuficiente în creșterea permeabilității GA-18- $\beta$ prin piele.

Keywords: $18-\beta$ glycyrrhetinic acid, enoxolone, anti-inflammatory drugs, skin penetration, penetration enhancers

\section{Introduction}

18- $\beta$ glycyrrhetinic acid (enoloxolone) (18- $\beta$ GA), one of pentacyclic triterpenes existing in the root of Glycyrrhiza glabra L., is available in skin products to remove inflammation, acne and allergy $[1,2]$. Antiinflammatory properties of $18-\beta$ GA relate to the inhibitory effect on the production of superoxide radicals by neutrophils, primary mediators of inflammation. It was reported that it provided anti-inflammatory effects by attenuating the formation of excessive nitric oxide, prostaglandin E2 and intracellular reactive oxygen species and by suppressing the expression of pro-inflammatory genes through the inhibition of NF$\kappa \mathrm{B}$ and phosphoinositide-3-kinase activity [3]. Its anti-tumoural activity was reported [4]. Furthermore, it has antibacterial and antifungal properties due to its steroid-like structure [5]. 18- $\beta$ GA is used in cosmeceuticals for its firming, moisturizing, whitening and antiaging effects to protect skin health and condition 
the skin. Its skin lightening effect is attributed to the inhibition of tyrosinase activity in melanocytes [6]. Penetration enhancers are often incorporated in topical products to achieve effective treatment via the transdermal route. They are sorption promoters that increase transdermal drug delivery by reducing skin barrier resistance [7, 8]. Glycols, terpenes and fatty acids are commonly used as penetration enhancers. They display different mechanisms through upper layers of the skin, mainly the stratum corneum [9]. They are able to promote delivery of both lipophilic and hydrophilic actives through the skin. Oleic acid (OA) is the most popular long chain fatty acid that enhances percutaneous drug absorption by disrupting the skin's intercellular lipid packing. A polar head group attached to its alkyl chain conducts its potential enhancement function. Whereas, propylene glycol (PG) causes insignificant disruption of intercellular lipid packing within stratum corneum bilayers. PG first penetrates through tissues itself and then alters the thermodynamic activity of the drug in a vehicle. Subsequently, the drug diffuses through the stratum corneum by modification of driving forces for diffusion. Limonene (L) is known as one of the most effective terpene enhancers. L displays a greater difference than many types of terpenes probably because it displays multiple mechanisms. L provides partial extraction of stratum corneum lipids and phase separation within stratum corneum lipid lamellae while increasing drug solubility in the skin $[10,11]$.

In this study, effects of various enhancers on penetration of 18- $\beta$ GA incorporated in traditional vehicles (hydrogel $(\mathrm{G})$, oil/water $(\mathrm{o} / \mathrm{w})$ emulsion (E) and oleaginous cream (OC)) were investigated for relieving inflammatory conditions of the skin. Physical characterization experiments were performed on topical formulations. Earlier studies demonstrated that in vivo and ex vivo tests on rats can be used to investigate characteristics required for skin delivery from an active or a vehicle $[12,13]$. Thus, effects of these penetration enhancers on anti-inflammatory effectiveness of $18-\beta$ GA were determined by hindpaw oedema test on Wistar albino rats. In the next step, penetration and permeation of the active through the skin was investigated in an $e x$ vivo study.

\section{Materials and Methods}

\section{Materials}

$18-\beta$ glycyrrhetinic acid (18- $\beta$ GA) was kindly provided from Nobel İlaç San. ve Tic. A.Ş., Turkey. Propylene glycol (PG), oleic acid (OA), DL-limonene (L) and Tween ${ }^{\circledR} 80$ were purchased from Merck (Germany). Cetyl alcohol and liquid paraffin were purchased from Sigma-Aldrich (Germany). Xanthan gum was purchased from Inner Mongolia Jianlong Biochemical Co., Ltd. (China). All other reagents and chemicals were of analytical grade.

\section{Topical formulations}

Compositions of base 18- $\beta$ GA formulations ( $G, E$ and $\mathrm{OA}$ ) are presented in Table I. Base hydrogel $(\mathrm{G}), \mathrm{o} / \mathrm{w}$ emulsion (E) and oleaginous cream (OC) formulations were prepared. The base $\mathrm{G}$ formulation containing xanthan gum in water was prepared by keeping the mixture for $24 \mathrm{~h}$. Then, $18-\beta$ GA was added to the hydrogel by stirring using a HS-100D propeller mixer (Daihan Scientific, Korea) at 400 rpm for $1 \mathrm{~min}$. The mixture was additionally kept in an ultrasonic bath (Bersonic, Turkey) for $1 \mathrm{~min}$. The base $\mathrm{E}$ formulation was prepared by addition of a hot aqueous Tween ${ }^{\circledR} 80$ solution $(7.7 \%$, w/w) to the lipophilic phase containing 18- $\beta$ GA, vaseline, liquid paraffin and cetyl alcohol by stirring at $70^{\circ} \mathrm{C}$ and $400 \mathrm{rpm}$ for 2 minutes. This emulsion was continued to be stirred until it cooled to the room temperature. The base OC formulation was prepared with addition of $18-\beta$ GA to the hot vaseline and liquid paraffin mixture by stirring at $70^{\circ} \mathrm{C}$ for $2 \mathrm{~min}$. and the mixture was cooled down to the room temperature. Methylparaben and propylparaben were incorporated into aqueous and lipophilic phases of formulations, respectively.

Table I

Constituents of base formulations

\begin{tabular}{lccc}
\hline Constituents $(\%)$ & G & E & OC \\
\hline 18- $\beta$ GA & 3 & 3 & 3 \\
Xanthan gum & 2 & - & - \\
Vaseline & - & 5 & 85 \\
Liquid paraffine & - & 17 & 12 \\
Cetyl alcohol & - & 5 & - \\
Tween ${ }^{\circledR}$ 80 & - & 5 & - \\
Distilled water & 95 & 65 & - \\
Methylparaben & 0.2 & 0.2 & - \\
Propylparaben & - & 0.2 & 0.2 \\
\hline gel; E, o/w emulsion; OC, oleaginous cream
\end{tabular}

Formulations containing penetration enhancers (PG, $\mathrm{OA}$ and L) were prepared under the same conditions (Table II) [14].

Table II

Formulations containing penetration enhancers

\begin{tabular}{lccc}
\hline \multirow{2}{*}{ Formulations } & \multicolumn{3}{c}{ Enhancers (\%) } \\
\cline { 2 - 4 } & PG & L & OA \\
\hline G* & - & - & - \\
G-PG & 10 & - & - \\
G-L & - & 1 & - \\
E* & - & - & - \\
E-PG & 10 & - & - \\
E-OA & - & - & 5 \\
E-L & - & 3 & - \\
OC $*$ & - & - & - \\
OC-PG & 10 & - & - \\
OC-OA & - & - & 5 \\
\hline
\end{tabular}

${ }^{*} \mathrm{G}, \mathrm{E}$ and $\mathrm{OC}$ are base formulations. PG, propylene glycol; $\mathrm{L}$, limonene; OA, oleic acid 
Quantification of 18- $\beta$ GA

UV spectroscopy and HPLC methods for quantification of 18- $\beta$ GA in samples obtained during experiments were validated according to the ICH guideline [15]. Thus, both of UV spectroscopy and HPLC methods were confirmed to be fit for their intended purpose during the research. Linearity, intra-day and interday precision, accuracy, recovery and specifity were determined to verify methods. Each verification analysis was repeated 6 times.

UV spectroscopy analysis. Analytical quantification by UV spectroscopy (Shimadzu Spectrophotometer UV-1700, Japan) was performed to investigate the solubility of 18- $\beta$ GA and in vitro drug release properties of formulations in the receptor phase. $\mathrm{pH}$ 7.4 phosphate buffer solution:ethanol:propylene glycol (PBS:EtOH:PG) (2:1:1) mixture was used as the receptor phase. This method was preferred, since it's a rapid, cost-efficient and reproducible technique with proper detection limits for such experiments. For this purpose, a calibration curve was drawn using concentrations of standard 18- $\beta$ GA solutions $(2,4$, $6,8,10$ and $12 \mu \mathrm{g} / \mathrm{mL}$ ) against absorbance values obtained at $256 \mathrm{~nm}$.

HPLC analysis. Analytical quantification by HPLC was performed to investigate ex vivo skin penetration characteristics of 18- $\beta$ GA. A HPLC apparatus (Shimadzu LC-20AT) was equipped with an UV detector (Shimadzu SPD-20A-UV), an autosampler (Shimadzu SIL-20A) and a column oven (Shimadzu CTO-10AS) kept at $40^{\circ} \mathrm{C}$. A GL Sciences Inertsil C18 column (150 $\mathrm{mm} \times 4.6)$ was also equipped to the apparatus for detection. Samples were detected under the $1 \mathrm{~mL} / \mathrm{min}$ flow rate of the acetonitrile:0.02 PBS $(1: 1, \mathrm{v} / \mathrm{v})$ mixture as the mobile phase at $248 \mathrm{~nm}$. A stock standard solution of 18- $\beta$ GA was prepared in the receptor phase at a concentration of $0.1 \mathrm{mg} / \mathrm{mL}$. A working standard solution of $18-\beta$ GA was also prepared at the concentration of $10 \mu \mathrm{g} / \mathrm{mL}$ by using the same solvent. To evaluate linearity of the method under the selected conditions, drug determination was carried out at six concentrations $(6.25-500 \mathrm{ng} / \mathrm{mL})$ in the mobile phase for the calibration curve.

Solubility of 18- $\beta$ GA in the receptor phase

The solubility of $18-\beta$ GA was determined in the receptor phase according to the method reported in USP XIX [14, 16]. $10 \mathrm{~mL}$ of a pH 7.4 PBS:EtOH:PG $(2: 1: 1, \mathrm{v} / \mathrm{v} / \mathrm{v})$ mixture as the receptor phase were placed in four $25 \mathrm{~mL}$ flasks for this purpose. A quantity of 18- $\beta$ GA was placed in each flask which was greater than the quantity expected to dissolve in the receptor phase. Flasks were tightly closed and they were placed in a constant temperature water bath (Daihan Scientific, Korea) at $32 \pm 0.5^{\circ} \mathrm{C}$. The apparatus was maintained under a continuous agitation at $160 \mathrm{rpm}$ for $24 \mathrm{~h}$. Dispersions were then filtered through $S \& S^{5893}$ blue ribbon papers $(2 \mu \mathrm{m}$ pore size, Schleicher \& Schuell, Germany). Measured portions of clear supernatants were removed and properly diluted. The solubility of $18-\beta$ GA in the receptor phase was determined spectrophotometrically at $256 \mathrm{~nm}$.

In vitro drug release from formulations

$0.45 \mu \mathrm{m}$ cellulose acetate membranes (Sartorius, Germany) were used between two halves of Franztype diffusion cells with $3.15 \mathrm{~cm}^{2}$ surface area and $33.2 \mathrm{~mL}$ volume [17]. Receptor chamber of diffusion cells were filled with the receptor phase. 0.5 gram of topical formulation was placed in the donor phase on to the membrane. The receptor phase was kept at a constant temperature of $32 \pm 0.5^{\circ} \mathrm{C}$ during this study. Samples were taken from the receptor phase at certain time intervals. Cumulative amounts of released 18- $\beta$ GA were determined by UV spectroscopy at $256 \mathrm{~nm}$ after proper dilution of samples. They were plotted as a function of time. Drug release profiles were evaluated by using different kinetic models (zero order, first order and Higuchi square-root model) $[18,19]$. " $n$ " values of Korsmeyer-Peppas kinetic model were considered to specify drug release mechanisms, especially when drug release comprises more than one type of release mechanisms.

In vivo assessment of anti-inflammatory effects of topical formulations

For this purpose, Wistar Albino rats (150 - $200 \mathrm{~g})$ were provided from “Aziz Sancar" Institute of Experimental Medicine (formerly known as DETAE, Istanbul University Institute for Experimental Medicine). The in vivo experimental protocol was approved by the Local Ethical Committee of Animal Experiments at the same institute (06.03.2014, No. 2014/30). Animals were housed in plastic cages at a constant temperature $\left(22 \pm 1^{\circ} \mathrm{C}\right)$ and humidity $(60 \pm 1 \%)$ under $12 \mathrm{~h}$ lightdark cycles. They were given the standard laboratory diet and tap water ad libitum. Rats were acclimated to the laboratory at least 7 days prior to experiments. Animals were divided into 12 groups of 3 animals (Table III). Hindpaws of rats were measured with a plethysmometer (Ugo Basile, Italy) and paw volumes $(\mathrm{mL})$ were obtained. While right hindpaws of animals were used for control, oedema was provided on their left hindpaws. The first group was the blank group treated with $0.25 \%$ (w/v) CMC-Na aqueous solution orally. $18-\beta$ GA was suspended in $0.25 \% \mathrm{CMC}-\mathrm{Na}$ aqueous solution $(0.3 \%, \mathrm{w} / \mathrm{v})$ for application to the oral group $(18 \mathrm{mg} / \mathrm{kg})$. Oedema in hindpaws of rats was provided using CMC-Na. Inflammation was induced by intraplantar injection of $0.1 \mathrm{~mL}$ of $1 \%(\mathrm{w} / \mathrm{v})$ CMC-Na solution in saline in the left hindpaw of all the rats 30 and $60 \mathrm{~min}$ later oral and topical applications. $0.2 \mathrm{~g}$ formulation containing $6 \mathrm{mg} 18-\beta$ GA was applied on 10 groups of rats for each topical formulation. Formulations were applied to the planter surface of the left hind paw by gently rubbing 50 times with the index finger. Intensity of oedema was assessed by measuring paw volumes with the 
blethysmometer. Measurements were carried out at predetermined time intervals for 6 hours. Swelling $\%$ and oedema inhibition $\%$ were calculated by using Equations 1 and 2 [20, 21]:

$$
\begin{gathered}
\text { Swelling }(\%)=\left[\left(V_{\mathrm{t}}-V_{0}\right) / V_{0}\right] * 100,(1) \\
\text { Oedema inhibition }(\%)=\left\{\left[\left(V_{\mathrm{t}}-V_{0}\right)_{\text {control }}-\right.\right. \\
\left.\left.\left(V_{\mathrm{t}}-V_{0}\right)_{\text {application }}\right] /\left(V_{\mathrm{t}}-V_{0}\right)_{\text {control }}\right\} * 100,
\end{gathered}
$$

where $V_{0}$ is the mean volume of hindpaws before application and $V_{\mathrm{t}}$ is the mean volume after drug application by oral and transdermal routes at time $(\mathrm{t})$.

Table III

Animal groups for determination of antiinflammatory effects of formulations

\begin{tabular}{cc}
\hline Groups & Application \\
\hline Blank & Oral 0.25\% CMC-Na aqueous solution \\
Oral susp. & Oral 18- $\beta$ GA aqueous suspension \\
& $(20 \mathrm{mg} / \mathrm{kg})$ \\
G & Topical application \\
G-PG & \\
G-L \\
E \\
E-PG \\
E-OA \\
E-L \\
OC \\
OC-PG \\
OC-OA \\
\hline Eand OC are base formulations. PG, propylene glycol; L, \\
monene; OA, oleic acid
\end{tabular}

\section{Ex vivo skin penetration and permeation studies}

Franz-type diffusion cells were used to determine 18- $\beta$ GA permeation through the skin [22]. For ex vivo skin penetration and permeation assessments, abdomens of animals were precisely shaved 2 days prior to the in vivo study. Shaved full-thickness abdominal skins of rats were taken after they were sacrificed following the in vivo assessment. The underlying fatty tissue was removed by blunt dissection without damaging the epidermal surface. They were placed between two halves of cells. $0.5 \mathrm{~g}$ formulations were applied on the top of the skin placed on the donor chamber of cells. The same solution, a pH 7.4 PBS: EtOH:PG (2:1:1) mixture, was used as the receptor phase. This study was continued at $37 \pm 1^{\circ} \mathrm{C}$ constant temperature for 48 hours [23, 24]. Amount of permeated $18-\beta$ GA was assayed in samples collected from the receptor phase by HPLC at predetermined time intervals. Three replicates were conducted for each formulation under the sink condition.

The cumulative amount $\left(Q_{\mathrm{n}}, \mathrm{mcg} / \mathrm{cm}^{2}\right)$ of $18-\beta \mathrm{GA}$ permeated through the skin was calculated using Equation 3. They were plotted as the function of time $(t, \mathrm{~h})[22,25]$.

$$
Q_{\mathrm{n}}=\frac{C_{\mathrm{n}} V_{0}+\sum_{i=1}^{n-1} C_{\mathrm{i}} V_{\mathrm{i}}}{A}
$$

where $C_{\mathrm{n}}$ is the $18-\beta \mathrm{GA}$ concentration in the receptor phase at the $n$th sampling interval. $A$ is the effective diffusion area (surface of the sample cell), $V_{0}$ and $V_{\mathrm{i}}$ are volumes of the receptor phase in the individual Franz cell and the sample, respectively. $\sum_{i=1}^{n-1} C_{i}$ is the sum of 18- $\beta$ GA concentration determined at sampling intervals 1 through $\mathrm{n}-1$.

The steady state flux of $18-\beta \mathrm{GA}\left(\mathrm{J}_{\mathrm{s}}, \mathrm{mcg} / \mathrm{cm}^{2} / \mathrm{h}\right)$ was determined from the slope of the linear part of the plot using the linear regression analysis $(r>0.99)$. It was calculated using Equation 4.

$$
J_{s}=C_{0} \frac{K D}{L}=C_{0} K_{\mathrm{p}}
$$

where $C_{0}$ is the constant drug concentration in the donor phase, $D$ is the diffusion coefficient, $L$ is the thickness of the membrane, $K$ is the partition coefficient of the drug and the vehicle, and $K_{\mathrm{p}}$ is the permeability coefficient.

Skin penetration of 18- $\beta$ GA was investigated recovering the same abdominal rat skins placed on the receptor chamber of Franz-type diffusion cells. Excess formulation in contact with the stratum corneum was carefully removed using cotton buds from the diffusion area [26]. Circular PVC adhesive tape pieces (Ve-ge ${ }^{\circledR}$, İzmir, Turkey) were provided in approx. $1 \mathrm{~cm}$ semidiameter. They were applied over the diffusion area. Subsequently, a light pressure was applied and they were removed with a forceps. The first two strips were discarded since they were containing the formulation lodged within crevices of the skin surface rather than being deposited within the tissue. The next 10 adhesive tape pieces were then applied to the same area using a uniform firm pressure and removed with uniform force rapidly. They were collected in a 25 $\mathrm{mL}$ flask for extracting 18- $\beta$ GA content. For this purpose, $10 \mathrm{~mL}$ ethanol was added to each flask for each formulation and all flasks were tightly closed. They were fixed in the constant temperature water bath at $25 \pm 1^{\circ} \mathrm{C}$. The apparatus was maintained at $160 \mathrm{rpm}$ continuous agitation for $24 \mathrm{~h}$. Dispersions were then filtered through $S \& S^{5893}$ blue ribbon papers $(2 \mu \mathrm{m}$ pore size, Schleicher $\&$ Schuell, Germany). A measured portion of clear supernatants was removed and their 18- $\beta$ GA content was determined by HPLC. Data treatment and statistics

Drug release and permeation profiles of formulations obtained from in vitro and ex vivo experiments and data obtained from tape stripping and in vivo experiments were statistically compared with one-way analysis of variance (ANOVA) test and the subsequent Fisher post hoc pairwise least significant difference test (PLSD). For this purpose, the Minitab ${ }^{\circledR} 18$ Statistical Software was employed. The significance level was set as $\alpha=0.05$. 


\section{Results and Discussion}

\section{Analytical quantification}

The purpose of validation is to show that processes involved in the development of a dosage form, production and analytical testing can be performed in an effective and reproducible manner. It was confirmed that both of the analytical methods were fit for their intended purpose during the research according to instructions of the ICH Harmonised Tripartite Guideline [15]. The UV absorption spectra of $18-\beta$ GA showed $\lambda_{\max }$ at $256 \mathrm{~nm}$ in the $\mathrm{pH} 7.4 \mathrm{PBS}: \mathrm{EtOH}: \mathrm{PG}$ (2:1:1) mixture (Figure 1a). The representative linear equation was $\mathrm{A}=\mathrm{aC}+\mathrm{b}$, where $\mathrm{A}$ is the absorbance, $\mathrm{a}$ is the slope, $\mathrm{C}$ is the concentration and $\mathrm{b}$ is the intercept. The regression equation was $\mathrm{A}=38.94 \mathrm{C}+0.267$ (correlation coefficient, $r=0.9991$ ). Additionally, the representative linear equation was determined as $\mathrm{A}=22.41 \mathrm{C}+1281.3(\mathrm{r}=0.9963)$ for HPLC analysis (Figure $1 \mathrm{~b}$ ). The retention time of $18-\beta \mathrm{GA}$ was obtained as $4.5 \mathrm{~min}$. Limits of detection (LOD) and quantification (LOQ) were $0.24 \mathrm{ng} / \mathrm{mL}$ and $0.74 \mathrm{ng} / \mathrm{mL}$, respectively. Relative standard deviations for accuracy, intra-day and inter-day precision of the methods were below $2 \%$. Recovery of $18-\beta$ GA was found to be between $100.64 \pm 0.42 \%$ and $101.37 \pm 0.52 \%$. a

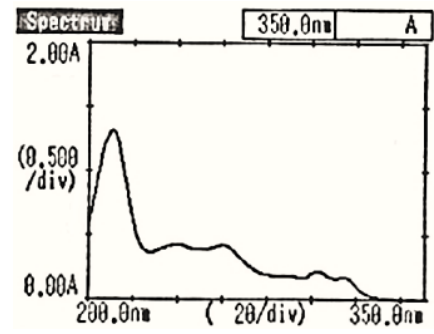

$m \mathrm{~m}$

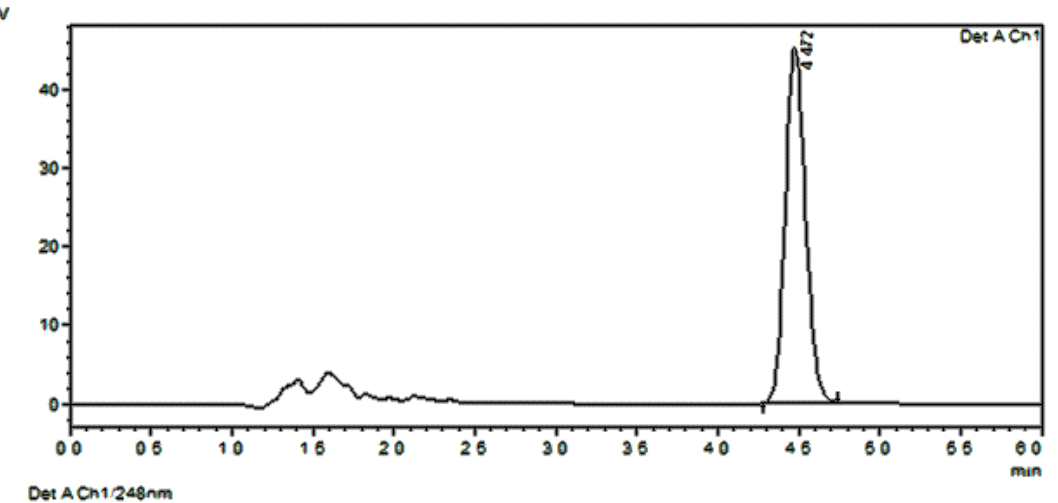

Figure 1.

The absorption spectra of 18- $\beta$ GA $(6 \mu \mathrm{g} / \mathrm{mL})$ in the pH 7.4 PBS:EtOH:PG $(2: 1: 1)$ mixture (a) and the HPLC graph of $18-\beta$ GA $(10 \mu \mathrm{g} / \mathrm{mL})$ in the acetonitrile:0.02 PBS $(1: 1)$ mixture $(\mathbf{b})$

Solubility of 18- $\beta$ GA in the receptor phase The solubility of 18- $\beta$ GA in the $\mathrm{pH}$ 7.4 PBS:EtOH:PG (2:1:1) mixture as the receptor phase was found to be $7.058 \pm 0.67 \mathrm{mg} / \mathrm{mL}$ at $32 \pm 0.5^{\circ} \mathrm{C}$. After trying different solvent mixtures, it was concluded that it would be appropriate to use this mixture as a receptor phase. In the case of lipophilic substances such as $18-\beta$ $\mathrm{GA}$, it is difficult to provide the sink condition. To achieve the sink condition, the receptor medium must have a relatively high capacity to solve or carry away the drug and the receptor media should not exceed $10 \%$ of drug solubility in the releasing matrix at the end of the test. Composition of the receptor phase can provide the suitable sink condition. The sink condition can be achieved by the use of alcohols or glycols in the receptor phase. For this purpose, EtOH and PG are often added to $\mathrm{pH} 7.4 \mathrm{PBS}$ up to $1: 1$ [27-30].

In vitro $18-\beta G$ A release from the formulations In vitro release study cannot be certainly regarded as a criterion for drug permeation through the skin. However, it may help someone to estimate some reasons of low drug penetration rate when penetration enhancing mechanism of penetration enhancers does not rule [31]. In a comparison of vehicles, the formulation $\mathrm{G}$ gave the highest drug release rate $(251.168 \mathrm{mcg} / \mathrm{h})$ followed by E ( $57.642 \mathrm{mcg} / \mathrm{h})$ and OC $(26.887 \mathrm{mcg} / \mathrm{h})$
(Figure 2 and Table IV). Effects of vehicles on 18- $\beta$ GA release rate were statistically significant $(p<0.05)$. This can be attributed to the low aqueous solubility of 18- $\beta$ GA [14]. To investigate the state of 18- $\beta$ GA in vehicles, all formulations were observed using a light microscope using a 20-times magnification (Carl Zeiss Axio Lab.A1, Carl Zeiss, Germany) (Figure 3). The drug was observed to be dispersed in the base gel formulation $(\mathrm{G})$. Influence of penetration enhancers on physical properties of formulations was also investigated in in vitro release study. PG addition to the hydrogel (G-PG) gave the highest release rate following the hydrogel without any penetration enhancer (G) $(p<0.05)$. Indeed, PG solved $18-\beta$ GA and provided better accommodation for $18-\beta$ GA within the polymeric network of the vehicle (G-PG). $18-\beta$ GA crystals were not observed clearly under the microscope. However, all hydrogel formulations (G, G-PG and G-L) displayed anomalous 18- $\beta$ GA transport that can be attributed to two mechanisms conducted drug release, diffusion and polymer relaxation (Table IV). Crystals weren't also detected since $18-\beta$ GA dissolved in the inner lipophilic phase of the $\mathrm{o} / \mathrm{w}$ emulsion and the hydrocarbon vehicle. In that case, increase in the lipophilicity of the vehicle resulted in slower drug release [32, 33]. Here, OA was confirmed 
FARMACIA, 2020, Vol. 68, 4

to increase affinity of the drug to the vehicle. It increased the 18- $\beta$ GA solubility in the emulsion (E-OA) while $\mathrm{PG}$ addition generally caused to a higher drug release rate even from OC. L was confirmed to cause slow release rate in the hydrogel vehicle similar to OA $(\mathrm{G}$ and G-L, $p<0.05$ ) while it did not affect $18-\beta$ GA release (E and E-L, $p>0.05)$. Apart from E-PG, 18- $\beta$ GA release from emulsion formulations (E, E-OA and $\mathrm{E}-\mathrm{L}$ ) were found to fit to anomalous transport mechanism. All oleaginous formulations (OC, OCPG and OC-OA) displayed 18- $\beta$ GA release conducted by diffusion.

Table IV

Release parameters of 18- $\beta$ GA from formulations for 6 hours and kinetic modelling of release profiles

\begin{tabular}{|c|c|c|c|c|c|c|c|c|c|c|c|}
\hline \multirow{3}{*}{ 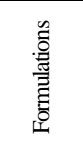 } & \multirow{3}{*}{$\begin{array}{c}Q \\
\left(\mathrm{mcg} / \mathrm{cm}^{2}\right)\end{array}$} & \multirow{3}{*}{$\begin{array}{c}\text { Release } \\
\text { rate } \\
\left(\mathrm{mcg} / \mathrm{cm}^{2} /\right. \\
\mathrm{h})\end{array}$} & \multicolumn{8}{|c|}{ Kinetic models } & \multirow{3}{*}{$\begin{array}{l}\text { Dominant } \\
\text { release } \\
\text { mechanism }\end{array}$} \\
\hline & & & \multicolumn{2}{|c|}{$\begin{array}{c}\text { Zero order } \\
{\left[Q_{t}=Q_{0}+k_{0} \mathrm{t}\right]}\end{array}$} & \multicolumn{2}{|c|}{$\begin{array}{c}\text { First order } \\
{\left[Q_{t}=Q_{\infty}\left(1-e^{-k t}\right)\right]}\end{array}$} & \multicolumn{2}{|c|}{$\begin{array}{l}\text { Higuchi model } \\
{\left[Q_{t}=Q_{0}+k_{\mathrm{H}} \mathrm{t}^{1 / 2}\right]}\end{array}$} & \multicolumn{2}{|c|}{$\begin{array}{c}\text { Korsmeyer-Peppas model } \\
{\left[\log \left[Q_{t} / Q_{\infty}\right]=\log k+n \log t\right]}\end{array}$} & \\
\hline & & & $\mathrm{r}$ & $k_{o}$ & $\mathrm{R}$ & $\mathrm{k}_{1}$ & $\mathrm{r}$ & $\mathrm{D}$ & $\mathrm{r}$ & $\mathrm{n}$ & \\
\hline G & $\begin{array}{c}1504 \pm \\
10.33\end{array}$ & $\begin{array}{l}251.17 \pm \\
1.73\end{array}$ & 0.9930 & 249.80 & 0.9540 & 0.35 & 0.9885 & 793.05 & 0.9972 & 0.83 (non-Fickian) & Anomalous \\
\hline G-PG & $\begin{array}{l}1245.12 \\
\pm 35.78\end{array}$ & $\begin{array}{c}207.94 \pm \\
5.98\end{array}$ & 0.9948 & 228.72 & 0.9467 & 0.50 & 0.9820 & 720.05 & 0.9949 & 0.99 (non-Fickian) & Anomalous \\
\hline G-L & $\begin{array}{l}299.31 \pm \\
9.36\end{array}$ & $\begin{array}{l}49.98 \pm \\
1.56\end{array}$ & 0.9928 & 38.26 & 0.9607 & 0.22 & 0.9945 & 122.23 & 0.9970 & 0.51 (nor & lous \\
\hline $\mathrm{E}$ & $\begin{array}{l}345.16 \pm \\
25.01\end{array}$ & $\begin{array}{l}57.64 \pm \\
4.18\end{array}$ & 0.9808 & 48.53 & 0.9335 & 0.25 & 0.9970 & 157.32 & 0.9981 & 0.60 (non-Fickian) & Ano \\
\hline E-PG & $\begin{array}{l}388.78 \pm \\
28.04\end{array}$ & $\begin{array}{l}64.93 \pm \\
4.68\end{array}$ & 722 & 43.76 & 53 & 7 & 57 & 142.92 & 0.9986 & 0.4 & on \\
\hline $\mathrm{E}-\mathrm{OA}$ & $\begin{array}{l}232 \pm \\
18.20\end{array}$ & $\begin{array}{l}38.74 \pm \\
3.04\end{array}$ & 0.9758 & 33.54 & 8991 & 0.28 & 0.9970 & 109.28 & 0.9887 & 0.69 (non-Fickian) & lous \\
\hline E-L & $\begin{array}{l}370.99 \pm \\
17.09\end{array}$ & $\begin{array}{l}61.96 \pm \\
2.85\end{array}$ & 0.9937 & 52.92 & 18 & 7 & 69 & 169.30 & 0.9991 & ian) & lous \\
\hline $\mathrm{OC}$ & $\begin{array}{c}161 \pm \\
7.86\end{array}$ & $\begin{array}{c}26.89 \pm \\
1.31\end{array}$ & 0.8998 & 15.59 & 0.8507 & 0.14 & 0.9530 & 52.67 & 0.9691 & 0.36 (Fickian) & sion \\
\hline $\begin{array}{l}\text { OC- } \\
\text { PG }\end{array}$ & $\begin{array}{l}317.37 \pm \\
14.68\end{array}$ & $\begin{array}{l}53.00 \pm \\
2.45\end{array}$ & 0.9810 & 24.87 & 0.9632 & 0.11 & 50 & 79.65 & 0.9847 & 0.24 (Fickian) & Diffusion \\
\hline $\begin{array}{l}\text { OC- } \\
\text { OA }\end{array}$ & $\begin{array}{c}298.49 \pm \\
8.21\end{array}$ & $\begin{array}{c}49.85 \pm \\
1.37\end{array}$ & 0.9953 & 39.03 & 0.9651 & 0.22 & 0.9948 & 124.41 & 0.9951 & 0.49 (Fickian) & Diffusion \\
\hline
\end{tabular}

$Q$ : cumulative amount of drug released; $Q_{t}$ and $Q_{0}$ : quantity of drug released at time $\mathrm{t}$ and in the release medium at $\mathrm{t}=0$, respectively; r: correlation coefficient; $k_{1}, k_{0}$, and $k_{\mathrm{H}}$ rate constants of the Zero order, First order and Higuchi kinetic models, respectively. $Q_{\mathrm{t}} / Q_{\infty}$ fractional release of drug, $k$ kinetic constant, and $n$ diffusion exponent of the release mechanism (slope).

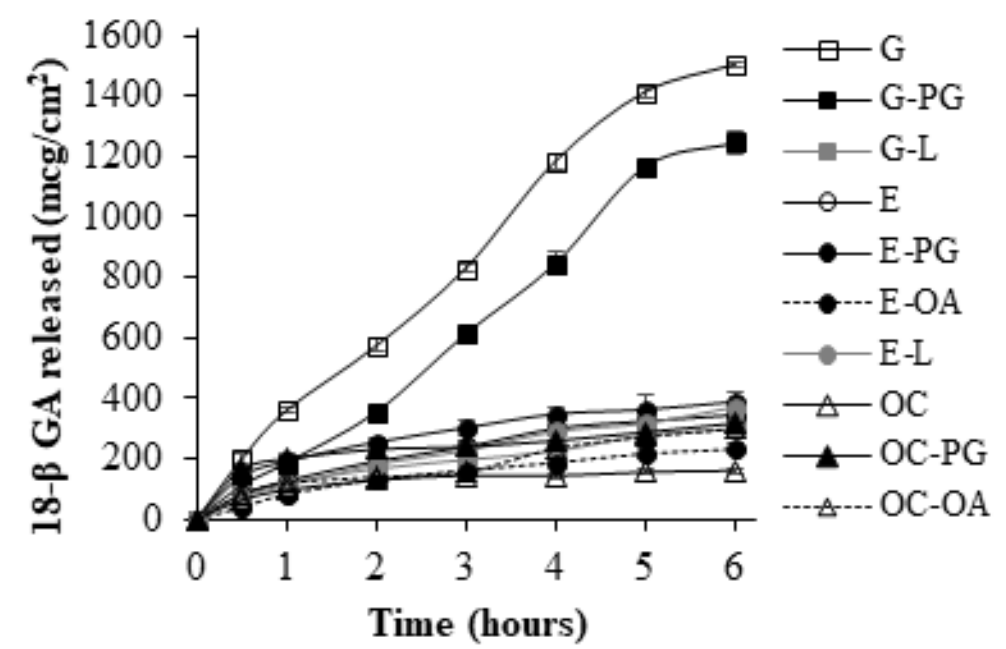

Figure 2.

18- $\beta$ GA release profiles from the topical formulations in the $\mathrm{pH}$ 7.4 PBS:EtOH:PG (2:1:1) mixture 
FARMACIA, 2020, Vol. 68, 4
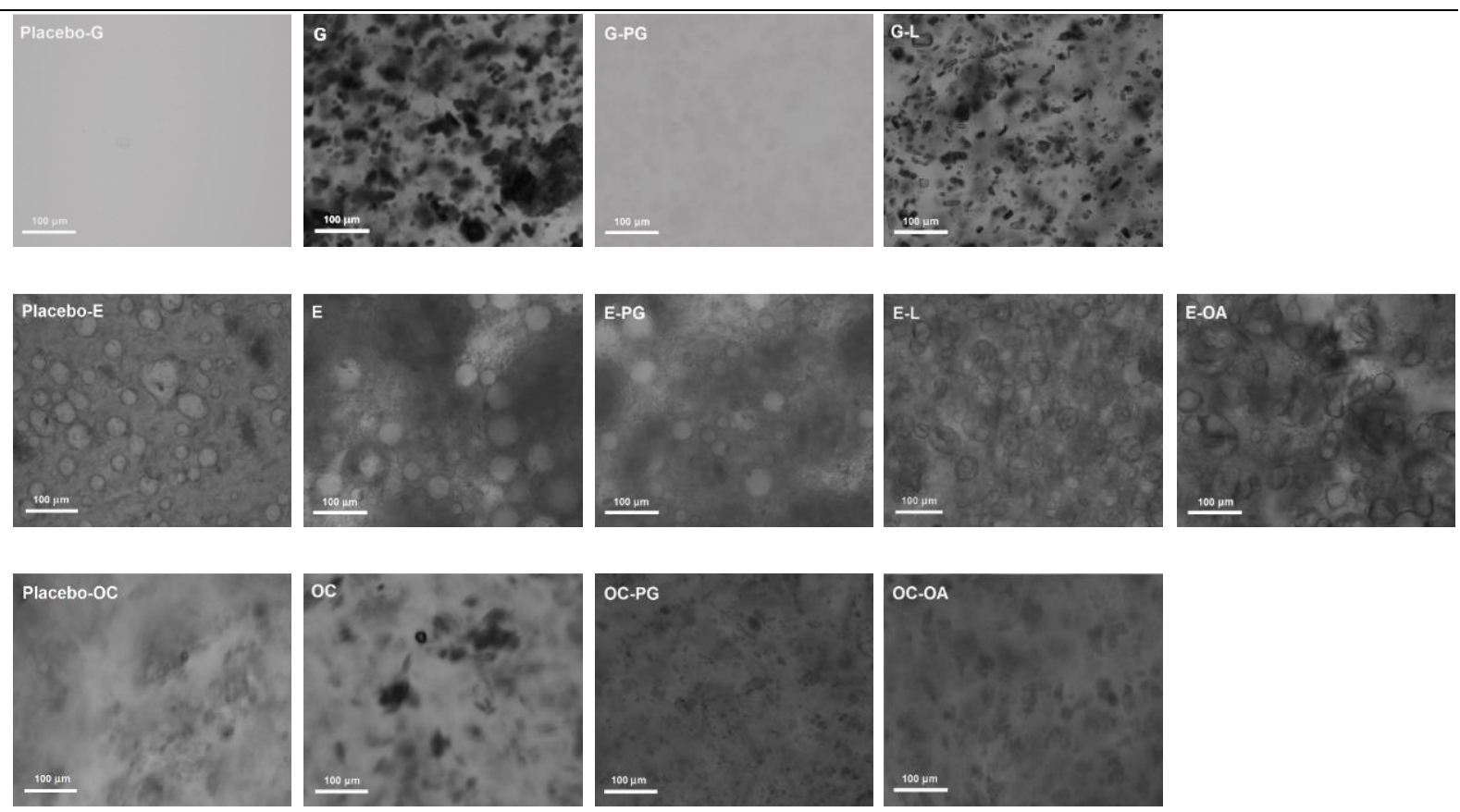

Figure 3.

Light microscope images of formulations (20x)

In vivo assessment of anti-inflammatory effect

The highest oedema inhibition was determined after oral application of the 18- $\beta$ GA suspension to rats in comparison with topical formulations as we expected (Figure 4) $(p<0.05)$. Anti-inflammatory effect occurred within 1 hour and increased by time. Subsequently, E displayed the highest oedema inhibition followed by OC, when $\mathrm{G}$ did not affect to oedema of hind paws of the rats (Figures 5 and 6$)(p<0.05)$. Addition of
PG to base formulations gave significantly higher efficacy compared to other penetration enhancers, $\mathrm{L}$ and OA $(p<0.05)$. This effect was more obvious in the emulsion formulation $(\mathrm{E})(p<0.05)$. Penetration enhancing effect of OA and L was found statistically insignificant and they were unsuitable penetration enhancers for topical formulations of $18-\beta$ GA with different polarity.

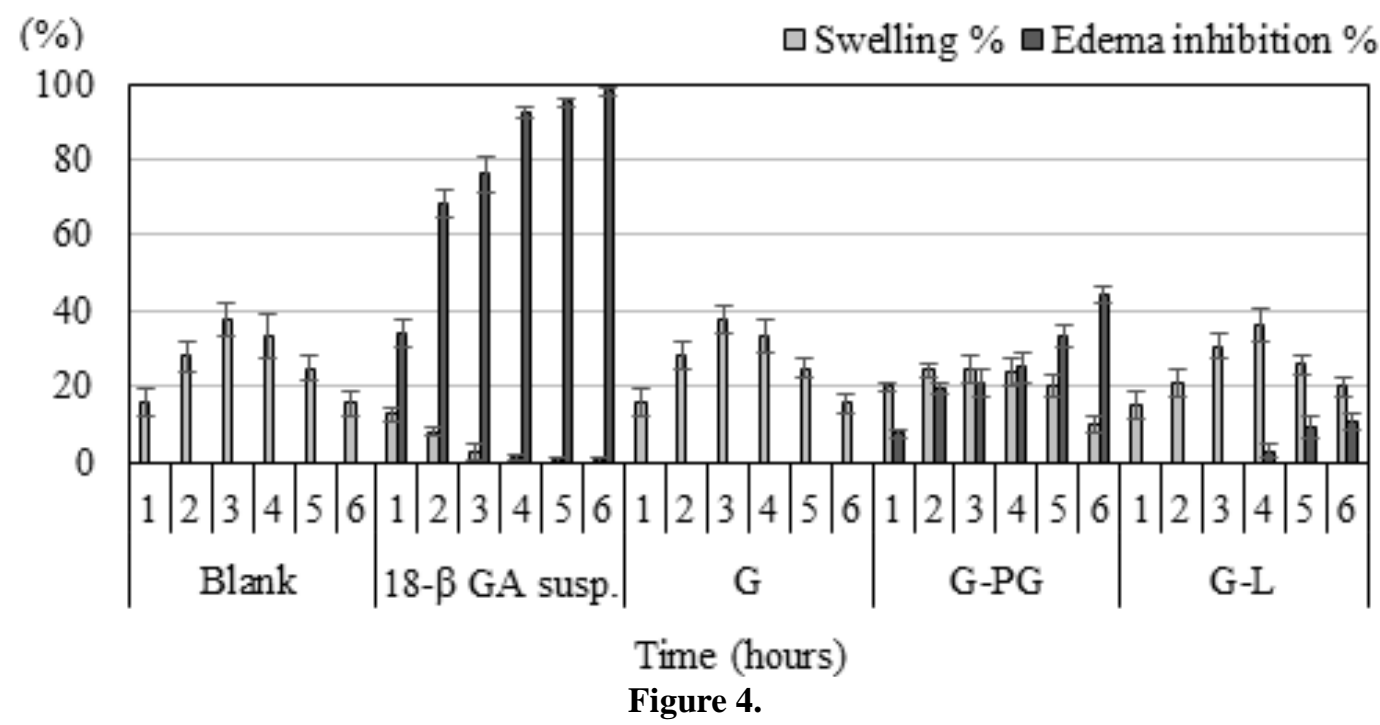

Swelling $\%$ and oedema inhibition $\%$ after oral and topical application of the 18- $\beta$ GA suspension and hydrogels to Wistar albino rats $(n=3)$ 


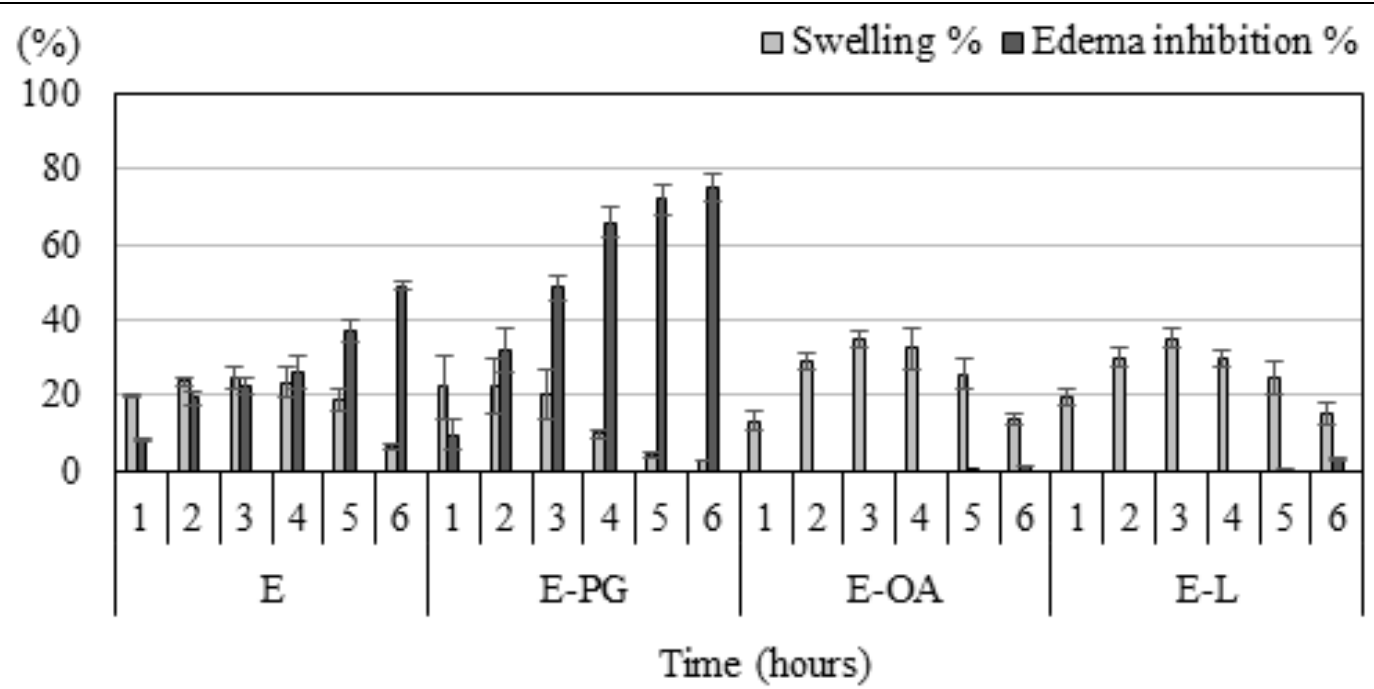

Figure 5.

Swelling $\%$ and oedema inhibition $\%$ after topical application of $18-\beta \mathrm{GA}$ o/w emulsions to Wistar albino rats $(\mathrm{n}=3)$

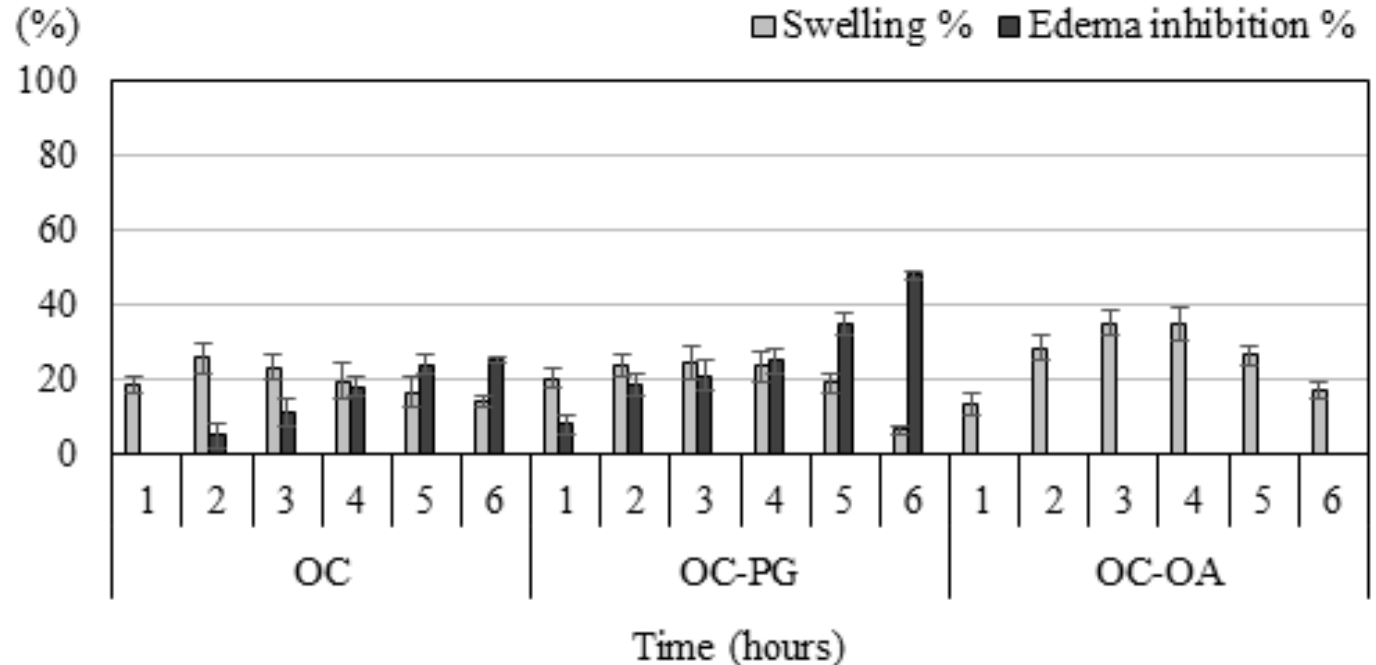

Figure 6.

Swelling $\%$ and oedema inhibition $\%$ after topical application of $18-\beta$ GA oleaginous creams to Wistar albino rats $(n=3)$

Ex vivo skin permeation and penetration study

Results obtained from the ex vivo skin permeation study were confirmed to be consistent with in vivo assessment of anti-inflammatory effect of $18-\beta$ GA. Oedema inhibition was determined to be accompanied by drug permeation. 18- $\beta$ GA permeation from topical formulations through the rat skin was determined to depend on the formulation and type of the penetration enhancer. The highest 18- $\beta$ GA permeation from base formulations was obtained with $\mathrm{E}$ followed by $\mathrm{OC}$ and G, respectively (Figure 7 and Table V) $(p<0.05)$. Furthermore, any drug permeation has not observed from G. This can be attributed to the insolubility and the crystalline state of 18- $\beta$ GA suspended in the hydrogel (Figure 3). If $18-\beta$ GA had dissolved in the structure of the xanthan gum hydrogel, the first phase required for transfer of its molecules through a skin pathway would have been completed for penetration process.

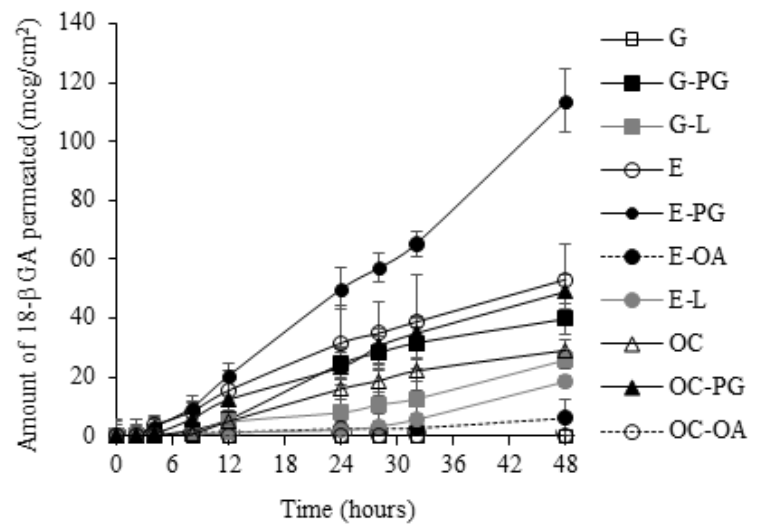

Figure 7.

Penetration profiles of $18-\beta$ GA through the abdominal rat skin $(\mathrm{n}=3)$ 
Permeation parameters of 18- $\beta$ GA through the skin

\begin{tabular}{lccccc}
\hline Formulations & $Q_{\mathrm{n}}\left(\mathrm{mcg} / \mathrm{cm}^{2}\right)$ & $J_{\mathrm{s}}\left(\mathrm{mcg} / \mathrm{cm}^{2} / \mathrm{h}\right)$ & $K_{\mathrm{p}}(\mathrm{cm} / \mathrm{h})$ & Lag time & $\mathrm{r}$ \\
\hline $\mathrm{G}$ & $0 \pm 0$ & $\mathrm{n} / \mathrm{a}$ & $\mathrm{n} / \mathrm{a}$ & $\mathrm{n} / \mathrm{a}$ & $\mathrm{n} / \mathrm{a}$ \\
$\mathrm{G}-\mathrm{PG}$ & $39.81 \pm 8.80$ & $1.72 \pm 0.31$ & $1.15 \times 10^{-4} \pm 2.07 \times 10^{-5}$ & $4.65 \pm 0.58$ & 0.9927 \\
$\mathrm{G}-\mathrm{L}$ & $25.89 \pm 5.91$ & $0.75 \pm 0.13$ & $0.50 \times 10^{-4} \pm 0.87 \times 10^{-5}$ & $24.12 \pm 0.79$ & 0.9970 \\
$\mathrm{E}$ & $53.19 \pm 22.25$ & $1.38 \pm 0.39$ & $0.92 \times 10^{-4} \pm 2.60 \times 10^{-5}$ & $4.11 \pm 0.24$ & 0.9921 \\
E-PG & $113.71 \pm 9.55$ & $2.48 \pm 0.13$ & $1.65 \times 10^{-4} \pm 0.87 \times 10^{-5}$ & $3.92 \pm 0.66$ & 0.9968 \\
E-OA & $6.17 \pm 6.28$ & $0.19 \pm 0.26$ & $0.13 \times 10^{-4} \pm 1.73 \times 10^{-5}$ & $26.08 \pm 2.89$ & 0.9919 \\
E-L & $18.58 \pm 2.32$ & $0.71 \pm 0.06$ & $0.47 \times 10^{-4} \pm 0.40 \times 10^{-5}$ & $24.02 \pm 0.11$ & 0.9919 \\
OC & $29.17 \pm 3.85$ & $0.87 \pm 0.18$ & $0.58 \times 10^{-4} \pm 1.20 \times 10^{-5}$ & $7.88 \pm 0.19$ & 0.9986 \\
OC-PG & $49.09 \pm 10.67$ & $1.18 \pm 0.18$ & $0.79 \times 10^{-4} \pm 1.20 \times 10^{-5}$ & $4.43 \pm 0.71$ & 0.9957 \\
OC-OA & $0 \pm 0$ & $\mathrm{n} / \mathrm{a}$ & $\mathrm{n} / \mathrm{a}$ & $\mathrm{n} / \mathrm{a}$ & $\mathrm{n} / \mathrm{a}$
\end{tabular}

$Q_{\mathrm{n}}$ : cumulative amount of $18-\beta$ GA permeated; $J_{\mathrm{s}}$ : steady state flux of $18-\beta \mathrm{GA} ; K_{\mathrm{p}}$ : permeability coefficient; r: correlation coefficient; n/a: not applicable.

Influence of penetration enhancers (PG, OA and L) was analysed in the respect of $18-\beta$ GA permeation. We also attempted to prepare formulations containing isopropyl myristate and Transcutol ${ }^{\circledR}$ as penetration enhancers in addition to PG, OA and L. However, they did not give physically stable formulations at different concentrations. Thus, we decided to continue with PG, OA and L at concentrations that give physically stable formulations (Table II). Previous studies on similar topics also helped us to confirm concentrations of selected penetration enhancers [10, 34]. We also saw that $\mathrm{OA}$ and $\mathrm{L}$ were physically incompatible with $\mathrm{G}$ and $\mathrm{OC}$, respectively. It was found that only the incorporation of $\mathrm{PG}$ to vehicles enhanced the penetration rate of $18-\beta$ GA up to the $48^{\text {th }} \mathrm{h}(p<0.05)$. However, $\mathrm{OA}$ and L significantly decreased the permeation rate contrary to our expectations. Addition of PG to formulation $\mathrm{E}$ improved drug permeation indicating the most effective formulation (E-PG) followed by E, OC-PG and G-PG, respectively $(p<0.05)$. OA possibly increased the affinity of $18-\beta$ GA to the lipophilic phase of $\mathrm{E}$ and the lipophilic structure of OC. In the meantime, weakness in the skin barrier caused by disturbing the intercellular lipid packing was insufficient for $18-\beta \mathrm{GA}$ permeation. Decreased skin/vehicle partitioning of 18- $\beta$ GA prevented ion-pair formation between drug and fatty acids of the stratum corneum. $\mathrm{L}$ was also insufficient as a penetration enhancer for 18- $\beta$ GA. Whereas, PG possibly provided an environment facilitating diffusion of $18-\beta$ GA even by modification of the driving force for its diffusion. Steady-state flux $(J S)$ and lag time of formulations were variable as can be seen in Table V. Lag times for $\mathrm{E}$ and formulations containing PG (G-PG, E-PG and OC-PG) were earlier (about 4 hours) than other formulations. Formulations displaying permeation followed zero order release kinetics. Amounts $\%$ of $18-\beta$ GA in the stratum corneum and the receptor phase for each formulation after 48 hours are shown in Figure 8. Amounts of 18- $\beta$ GA extracted from the stratum corneum were significantly higher than determined in the receptor phase. These results showed that the amount of $18-\beta$ GA penetrated through the skin occurred with E-PG, OC-PG, E and G-PG from the highest to the lowest, respectively. And they were also consistent with the results of the in vivo assessment on anti-inflammatory effects of formulations.

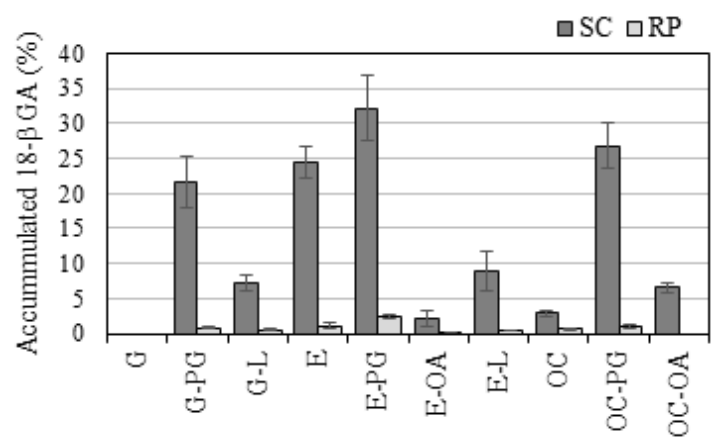

Figure 8.

Cumulative amount of 18- $\beta$ GA (\%) retained in the stratum corneum (SC) of Wistar albino rat skins and remained in the receptor phase (RP) after $48 \mathrm{~h}$ application of different formulations

\section{Conclusions}

It was concluded that in vivo and ex vivo studies performed on Wistar albino rats provided us information to estimate at least two conditions required for skin penetration of $18-\beta$ GA. Highly hydrophilic vehicles are not suitable for transdermal delivery of $18-\beta$ GA. Propylene glycol is the most proper penetration enhancer for transdermal delivery of $18-\beta$ GA in vehicles with different polarity. Based on the information obtained from the study, the o/w emulsion formulation containing propylene glycol can be recommended for penetration of 18- $\beta$ GA to alleviate the inflammatory and painful conditions of the skin.

\section{Acknowledgement}

This study was supported by the Research Fund of Istanbul University. Project No. 22237.

\section{Conflict of interest}

The authors declare no conflict of interest. 


\section{References}

1. Sweetman SC, Martindale: The Complete Drug Reference. $36^{\text {th }}$ ed. Pharmaceutical Press; 2009.

2. Obolentseva GV, Litvinenko VI, Ammosov AS, Popova TP, Pharmacological and therapeutic properties of licorice preparations (A review). Pharm Chem J., 1999; 33: 24-31.

3. Wang CY, Kao TC, Lo WH, Yen GC, Glycyrrhizic acid and 18ß-glycyrrhetinic acid modulate lipopoly saccharide-induced inflammatory response by suppression


J Agr Food Chem., 2011; 59(14): 7726-7733.

4. Haghshenas V, Fakhari S, Mirzaie S, Rahmani M, Farhadifar F, Glycyrrhetinic acid inhibits cell growth and induces apoptosis in ovarian cancer A2780 cells. Adv Pharm Bull., 2014; 4(Suppl 1): 437-441.

5. Wang L, Yang R, Yuan B, Liu Y, Liu C, The antiviral and antimicrobial activities of licorice, a widely-used Chinese herb. Acta Pharm Sin B., 2015; 5(4): 310-315.

6. Um SJ, Park MS, Park SH, Han HS, Kwon YJ, Sin HS, Synthesis of new glycyrrhetinic acid (GA) derivatives and their effects on tyrosinase activity. Bioorg Med Chem., 2003; 11(24): 5345-5352.

7. Trommer H, Neubert RH, Overcoming the stratum corneum: The modulation of skin penetration. Skin Pharmacol Physiol., 2006; 19(2): 106-121.

8. Lopes LB, Garcia MT, Bentley MV, Chemical penetration enhancers. Ther Deliv., 2015; 6(9): 1053-1061.

9. Pathan IB, Setty CM, Chemical penetration enhancers for transdermal drug delivery systems. Trop J Pharm Res., 2009; 8(2): 173-179.

10. Peycheva S, Apostolova E, Peychev Z, Gardjeva P, Slavov A, Murdjeva M, Changes in the cytokine levels in adolescents with gingivitis after treatment with propolis. Farmacia, 2019; 67(2): 360-366.

11. Moghimi HR, Williams AC, Barry BW, A lamellar matrix model for stratum corneum intercellular lipids. V. Effects of terpene penetration enhancers on the structure and thermal behaviour of the matrix. Int $J$ Pharm., 1997; 146(1): 41-54.

12. Abd E, Yousef SA, Pastore MN, Telaprolu K, Mohammed YH, Skin models for the testing of transdermal drugs. Clin Pharmacol., 2016; 8: 163-176.

13. Todo $\mathrm{H}$, Transdermal permeation of drugs in various animal species. Pharmaceutics, 2017; 9(3): 33: 1-11.

14. Karaman EF, Preparation of topical formulations of enoxolone in different vehicles to be applied to skin [Master's Thesis]. Istanbul: Istanbul University; 2013.

15. ICH Harmonised Tripartite Guideline: Validation of Analytical Procedures: Text and Methodology Q2 (R1). Harmonization Co, Editor; 2005.

16. Üner M, Karaman EF, Preliminary studies on solid lipid microparticles of loratadine for the treatment of allergic reactions via the nasal route. Trop J Pharm Res., 2013; 12(3): 287-293.

17. Salerno C, Carlucci AM, Bregni C, Study of in vitro drug release and percutaneous absorption of fluconazole from topical dosage forms. AAPS PharmSciTech., 2010; 11(2): 986-993.

18. Higuchi T, Mechanism of sustained action medication. Theoretical analysis of rate of release of solid drugs dispersed in solid matrices. J Pharm Sci., 1963; 52(12): 1145-1149.

19. Korsmeyer RW, Gurny R, Doelker E, Buri P, Peppas NA, Mechanisms of solute release from porous hydrophilic polymers. Int J Pharm., 1983; 15(1): 25-35.

20. Yener G, Üner M, Gönüllü Ü, Yıldırım S, Kılıç P, Design of meloxicam and lornoxicam transdermal patches: Preparation, physical characterization, ex vivo and in vivo studies. Chem Pharm Bull., 2010; 58: 1466-1473.

21. Tsai CC, Lin CC, Anti-inflammatory effects of Taiwan folk medicine 'Teng-Khia-U' on carrageenan-and adjuvant-induced paw edema in rats. $J$ Ethnopharm., 1999; 64(1): 85-89.

22. Üner M, Yener G, Ergüven M, Karaman EF, Utku EG, Solid lipid nanoparticles and nanostructured lipid carriers of celecoxib for topical application preparation, characterization and drug penetration through rat skin. Curr Nanosci., 2014; 10(4): 532-542.

23. Jiang Q, Wu Y, Zhang H, Liu P, Yao J, Yao P, Chen J, Development of essential oils as skin permeation enhancers: penetration enhancement effect and mechanism of action. Pharm Biol., 2017; 55(1): 1592-600.

24. Pandit J, Garg M, Jain NK, Miconazole nitrate bearing ultraflexible liposomes for the treatment of fungal infection. J Liposome Res., 214; 24(2): 163-169.

25. Williams AC, Barry BW, Essential oils as novel human skin penetration enhancers. Int J Pharm., 1989; 57(2): R7-R9.

26. Houston DMJ, Bugert J, Denyer SP, Heard CM, Anti-inflammatory activity of Punica granatum L. (Pomegranate) rind extracts applied topically to $e x$ vivo skin. Eur J Pharm Biopharm., 2017; 112: 30-37.

27. Ueda CT, Shah VP, Derdzinski K, Ewing G, Flynn $\mathrm{G}$, Maibach H, Topical and transdermal drug products. Dissolution Technol., 2010; 17: 12-25.

28. Nastiti CMRR, Ponto T, Abd E, Grice JE, Benson HAE, Roberts MS, Topical nano and microemulsions for skin delivery. Pharmaceutics, 2017; 9(4): 1-25.

29. Londoño CA, Rojas J, Yarce CJ, Salamanca CH, Design of prototype formulations for in vitro dermal delivery of the natural antioxidant ferulic acid based on ethosomal colloidal systems. Cosmetics, 2019; 6: 1-18.

30. Bhandari KH, Lee DX, Newa M, Yoon SI, Kim JS, Kim DD, Kim JA, Yoo BK, Woo JS, Lyoo WS, Lee $\mathrm{JH}$, Choi HG, Yong CS, Evaluation of skin permeation and accumulation profiles of a highly lipophilic fatty ester. Arch Pharm Res., 2008; 31: 242-249.

31. Surber C, Smith E, The vehicle: The pharmaceutical carrier of dermatological agents. In: Gabard B, Elsner P, Surber C, Treffel P, editors. Dermatopharmacology of topical preparations. A product development-oriented approach. Berlin: Springer-Verlag; 2000; 5-21.

32. Watkinson RM, Guy RH, Oliveira G, Hadgraft J, Lane ME, Optimisation of cosolvent concentration for topical drug delivery III - influence of lipophilic vehicles on ibuprofen permeation. Skin Pharmacol Physiol., 2011; 24(1): 22-26.

33. Williams AC, Barry BW, Penetration enhancers. Adv Drug Deliv Rev., 2004; 56(5): 603-618.

34. Diez I, Peraire C, Obach R, Domenech J, Influence of d-limonene on the transdermal penetration of felodipine. Eur J Drug Metab Pharmacokinet., 1998; 23(1): 7-12. 